\title{
Empirical Approach of Leading the Academic Advising Process in Higher Education
}

\author{
Saeed Hameed Aldulaimi* \\ College of Administrative Sciences, Applied Science University (ASU), Bahrain
}

Submission: December 12, 2018; Published: January 03, 2019

*Corresponding author: Saeed Hameed Aldulaimi, College of Administrative Sciences, Applied Science University (ASU), Bahrain

\begin{abstract}
The current study aimed at revealing the reality of academic advising in Higher education as perceived and experienced by a head of academic advising committee. Furthermore, this study extant the literature by handling the lacks to provide convincing approach that advising has an impact on students in practice. The study revealed that produce a participating application perfect between the factors of the academic advising system and the student. Set the plan for every semester to determine the main actions that should be taken, and agenda is essential for successful academic advising process.

In addition, inform, suggest, counsel, discipline, coach, mentor and teach and the follow-up process with students at risk helps and empowers them to correct their direction and overcome current problems. Finally, developing the academic advisor's social capabilities to overcome the frontier of campus to enable them to move forward in their academic path. Recommendation of this study suggest that the academic advising generally tend to use online platform for advising which it has numerous portions that optimizing the application. Therefore, more studies should shed lights on the improvement of the online academic advising with the lack of social interaction.
\end{abstract}

Keywords: Academic Advising; Empirical Approach; Leadership; University; Higher Education

\section{Introduction}

In the contemporary advanced learning contexts, the university is one of the most important institutions of society, and since ancient times has been at the forefront a center of radiation for every new thought and knowledge, a platform from which the views of thinkers and scientists emerge philosophers and pioneers of reform and development. Universities have become institutions that no society can live in the era of dispensing them is that individuals in various scientific disciplines are at a high level; Is responsible for the management of modern life, so officials of the university education system are trying to increase its efficiency as far as possible.

Academic guidance services are an urgent need to achieve the goals of university education aimed at stimulating the talents of diverse students to grow academically and ethically integrated psychologically, socially and behaviorally, and prepare students in a manner consistent with their attitudes, abilities and values to the rapid development challenges in the community arena. Academic guidance is essential and necessary institutions, to discover the wishes and abilities of students, to identify their goals and to help them draw plans for them.

Despite academic advising's theoretical and professional development, extant literature lacks convincing evidence that advising has an impact on students in practice [1]. Previous studies have found a positive association between academic advising and student's retention and satisfaction [2,3]. "Good advising yields a good outcome in terms of understanding, planning, and applying strategies for academic success, while bad advising will be frustrating and may have a damaging effect on students' progress" [4]. Build a participation application to make effective link between the factors of the academic advising system in the benefit of the student.

The present manuscript focuses on the importance of understanding the attitudes of undergraduate students towards academic advising and throws light on the relevance of efficient academic advising systems in the technologically dynamic educational environment. Developmental advising seeks to provide a holistic approach to the student-faculty (advisor) relationship outside of the classroom environment, where the student can receive guidance and discuss topics such as coursework, career, and values. Consequently, there was a need to supply the audience with an accredited experience. This paper aims to fill that gap. In a sense, the rationale of this study was to manage the overwhelming amount of practices through the critical exploration, evaluation, and synthesis of the empirical results that merit reflection. What are the basic theoretical and practical directions of Academic Advising up to now and which approaches do faculties follow to achieve these goals? 


\section{Literature Review}

There is an increasing body of research which revealed that students often meet academic advisors for reasons other than academic issues and concerns [5]. An academic advisor traditionally has been defined as a staff member who ensures students' individual academic plans are consistent with their academic interests and abilities [6].

Developmental advising was first introduced by Crookston [7]. This approach is focused on helping students explore and define academic, career and life goals and pathways, and develop problem-solving and decision-making skills through collaborative and process-oriented advising. Descriptive advising remains the most widely used but certainly not enough. The descriptive advising provides information to students at specific times and in various ways, such as distributing brochures, pamphlets, pamphlets, manuals, holding limited personal meetings, or organizing awareness and education seminars on the nature of academic extension services.

The method of developmental advising was formulated in the literature and the legacy of guidance and academic advice in the early 1980s thanks to the efforts of Winston and Miller [8]. They defined it as a systematic process based on a close bilateral relationship between the student and his mentor whose goal is to assist the student in achieving his educational, professional, personal, and life goals by investing more and more in the resources and resources available at the university.

On the other hand, Crookston [9] described "academic guidance as a multi-faceted activity that achieves the maximum benefits that Crockstone has identified in the following:

1. Helping students determine their values, objectives and understanding

2. Helping students understand the nature and purpose of higher education and its mission

3. To provide the student with accurate and correct information about the educational options and requirements of the degree and the policies and regulations of the university and its formal procedures

4. Assist students in the ongoing monitoring and evaluation of academic progress

5. Help the student in the planning of an academic program consistent with his tendencies and abilities

6. Work to create an integrative formula between issued by the university and its possibilities and investment to achieve personal educational needs and aspirations of each student".

In this context, Light [10] establish had a relationship between academic advising and students' academic growth and stated that "good academic advising can have a profound impact on the academic growth of students" (p. 15). He also observed that such interactions may help a student find his or her place within the university and may also give a more satisfying college experience. Nutt $[11,12]$ describes academic advising as an integral part of how the student will perceive his or her relationship with the institution.

The prescriptive or traditional advising model is focused primarily on providing students with information directly related to their academic program and progress, such as academic policies, major/program requirements and course selection. Glennon is the first introduced a model for instructive advising services in 1975. "A defining feature of this approach is that contact is initiated by the advisor rather than the student" [13].

\section{Empirical Approach of Academic Advising}

Obviously, academic guidance in the higher education is an integral part of university education. Its purpose is to help students take responsibility for their learning and to develop meaningful educational plans consistent with their abilities, professional goals and goals of life. It includes helping students formulate important questions about their preparedness, their own interests, and the best learning path for everyone who wants advice. Counselors also assist students in discovering many campus resources and, more importantly, providing continuous encouragement to students; to use these resources and their purpose continuously.

There is quite believe that the interaction of students with faculty members who conduct their academic guidance inside and outside the classroom has a positive impact on their cognitive and intellectual development, which in turn increases the intrinsic value of learning and university education. In the same vein, Zalabak [14] believes that academic counselors play a vital role in helping the student and supporting him in his university experience. Therefore, their role should not stop when students are informed and informed of what courses or materials can be recorded, they dream and belong to become good citizens. Obviously, academic advising is part of the roles of the faculty member accredited in American universities and is therefore expected to assume its responsibilities in this regard and provide appropriate and appropriate extension service for students when required to do so.

The researcher was appointed to lead the Academic Advising Committee (AAC) in the Business Administration Department. The work of ensuring an effective advising process is a huge and important task. I understand that the academic advising process plays a vital role in guiding student to reach their potential and move forward confidently in their career path. Essentially, "academic advising has the advantage of providing students with repeated one-on-one interactions across multiple years" [15].

To accomplish this essential task, I prepared a plan for every semester to determine the main actions that should be taken and specify meeting time and agenda. Then, I chaired meetings with faculty to explain the role of the academic advisor and the plan for this semester. I explained the main objectives of the academic advising process and emphasized that students should be given 
an opportunity to meet their advisors throughout the learning process. Basically, I worked to ensure that academic advisors assisted students in successful completion of their degree programme through periodic coaching, mentoring and guiding the students through the university policies, regulations and assessment criteria. The nature of this initiative was to inform, suggest, counsel, discipline, coach, mentor and teach [16], and the follow-up process with students at risk helps and empowers them to correct their direction and overcome current problems.

Many academics classify student development into three different categories: psychosocial, social identity, and cognitivestructural development. Hence, academic advising encompasses discussion of life goals and building rapport with students to discuss respect personal issues that might represent a barrier to their academic progress. Therefore, I clarified the benefits of reaching students who may not have been motivated to seek advising; establishing at an early stage an advisor/advisee relationship; engaging in intentional degree planning; and providing individualized support [17]. Moreover, I worked on developing the academic advisor's social capabilities to hold discussions with students to overcome the frontier of campus and encourage students who have low academic scores to feel free in such discussion which aims at the end to enable them to move forward in their academic path. For this purpose, I organized and delivered a workshop for all staff on the key social skills needed to build effective advisor relationships with student, in order to assist students in the areas of engagement, academic planning, decision making, and problem resolution.

In the workshop I emphasized that advisors should take special care with students, at risk, by meeting them to discover the main reasons behind failure to score well in their courses. I prepared forms to organize the student-adviser meetings which include a list of causes of failure. Recently, I discussed with both Registration and Student Affairs Deanship to make those forms of academic advising available online to easily monitor the student advisor sessions and the improvement plan. In addition, digitizing academic advising process can help the advisor to improving student's success. In fact, regular reviews of student records can reveal potential problems which promote academic planning.

Bylaws for the Academic Advising Committee chair state that they are responsible for assessing that it is operating smoothly, so one of my responsibilities is annually evaluating the performance of every faculty, since all academic advisors are guided and informed about advising techniques, new policies, roles and responsibilities by the University Advisory Committee. Normally, I evaluate each advisor on their advising skills using the student advisory files and through student feedback regarding the benefits that the students have received. Advisors are evaluated on factors such as the number of students under their supervision, the frequency and regularity of their meetings, quality and content of their recommendations and advice and the adherence to University regulations and procedures.
In addition, the students can evaluate their Advisor at the end of each academic year using the Student Advisor Evaluation form. For outstanding success in chairing Academic Advising Committee at department level, recently, I was promoted to lead the AAC of the Administrative Science College, because the College Council had looked at my achievements during the last years in leading the AAC in the department level and was confident that I could lead the committee at the College level. In cooperation with Deanship of Student Affairs, I presented a seminar at the beginning of the current year attended by all academic staff in university to illustrate the main roles of academic advising and what is important to do in next stage.

The big challenge for me is to handle the problem of monitoring and advising students at risk to ensure they can fulfill their graduation requirements. There are many students at risk at the university who are identified and supported by our academic outreach initiatives. The peer counselors' program is one of these initiatives, where counselors are trained on how to identify students who have received low GPA results, low test results under guidance, and supervision by academic advisors, and peer counselors are split to share their resources and expertise; try, take advantage of the learning centers on campus.

We also believe that we can find the preventive measures we can take to reduce the likelihood of falling into a scenario at risk. Overall, academic advising plays a critical role in connecting students with learning opportunities to foster and support their engagement, success, and the attainment of key learning outcomes" [12]. The statistics show that in our college we successfully reduced the number of the students at risk, including those with a disability or health condition impacting on their academic performance. Also, I emphasize that academic advisors are responsible for ensuring that the students at risk develop an academic action plan to overcome the current challenges that put them in a position of academic risk.

\section{Conclusion}

Academic advising has become an imperative in higher education institutions, where members are the faculty is interested in aiding students to plan programs that help them achieve. Their academic and professional goals. Thus, academic guidance at the university level is a fundamental pillar for university education, because students and students need those who guide them and guide them to adapt to life with a view to highlighting the expected expectations of them about their orientation and abilities that need guidance in order to benefit the individual, the university and society.

We presented in this research an academic application which is used to reduce the cost, time, and effort for both the advisors and students. Some university student's face some problems with academic guidance may be due to various factors, including: unclear guidance philosophy and objectives and procedures for the student and even for academic advisors themselves, which may 
be reflected in students' attitudes towards mentoring academic importance to them. They may have negative attitudes in the face of some problems concerning their educational processes. Hebley $[18,19]$ stated that the academic guidance is part of the roles of the faculty member accredited in American universities and is therefore expected to assume its responsibilities in this regard and provide appropriate and appropriate extension service for students when required to do so.

There is essential need to build and design online application that lead to create learning community which lie in personal interactions with academic advisors and peer leaders, and participation online program. Start with tagging the new students who have recently joined the learning community from their first day on campus are taught to participate in interactions, workshops and initiatives that promote learning exploration, emphasize the importance of community relationships, and peer counselors guide new students in shaping and promoting community ties to use the resources available to them all.

This research conclude from the personal experience that the university should reconsider the current situation, where the allocation of one academic advisor to dozens of students and its role is focused on follow-up only, which should be reviewed, the academic guidance requires a greater bilateral interaction between the academic leader Of the members of the teaching staff and a specific number of students assigned to him not exceeding ten, are assisted in the selection of their academic specialization and commensurate with their goals and abilities and their personal aspirations and aspirations, without limiting the role of the main guide in follow-up scholastic defaulters.

Recommendation of this study suggest that the academic advising generally tend to use online platform for advising which it has numerous parts to further improve the functionality and application. Therefore, more studies should shed lights on the improvement of the online academic advising with the lack of social interaction.

\section{References}

1. Hagen, PL, Jordan, P (2008) Theoretical foundations of academic advising. In VN Gordon, WR Habley, TJ Grites, Associates (Eds), Academic advising: A comprehensive handbook. ( $2^{\text {nd }}$ edn). Jossey-Bass, San Francisco, California, USA.

2. Kohle Paul, W, Fitzpatrick, C (2015) Advising as servant leadership: Investigating student satisfaction. NACADA Journal 35(2): 28-35.
3. Vianden, J, Barlow, PJ (2015) Strengthen the bond: Relationships between academic advising quality and undergraduate student loyalty. NACADA Journal 35(2): 15-27.

4. Daramola, Emebo, Afolabi, Ayo, C (2014) Implementation of an intelligent course advisory expert system. Int. J. Adv. Res. Artif Intell 3: 6-12.

5. Brown, KL (2003) From Teacher-Centered to Learner-Centered Curriculum: Improving Learning in Diverse Classrooms. Education 124(1): 49-54.

6. Midgen, J (1989) The professional advisor. NACADA Journal 9(1): 6368.

7. White, ER (2006) Using CAS Standards for Self-Assessment and Improvement. NACADA Clearinghouse of Academic Advising Resources. National Academic Advising Association.

8. Winston, Ender, Miller, T (1982) Developmental approaches to academic advising. New directions for student services. Jossy-Bass, San Francisco, California, USA

9. Crookston, B (2009) A developmental view of academic advising as teaching. NACADA Journal 29 (1): 78-82.

10. Light, RJ (2001) Making the Most of College, Students Speak Their Minds, Cambridge, Harvard University Press.

11. Nutt, CL (2000) One-to-one advising. In VN Gordon, RH Wesley, Associates.

12. Campbell, SM, Nutt, CL (2008) Academic advising in the new global century: Supporting student engagement and learning outcomes achievement. Peer Review 10(1): 4-7.

13. Mottarella, KE, Fritzsche, BA, Cerabino (2004) What do Students Want in Advising? A Policy Capturing Study. NACADA Journal 24(1-2): 48-61.

14. Zalabak (2012) Advisors as interaction designers. NACADA Journal 32(1): $12-17$.

15. Pizzolato, JE (2008) Advisor, teacher, partner: Using the learning partnerships model to reshape academic advising. About Campus 13(1): $18-25$.

16. Kuhn, TL (2008) Historical foundations of academic advising. In VN Gordon, WR Habley, TJ Grites, Academic advising: A comprehensive handbook. ( $2^{\text {nd }}$ edn). Jossey-Bass, San Francisco, USA.

17. Donaldson, McKinney, Lee, Pino (2016) First-year community college students' perceptions of and attitudes toward intrusive academic advising. NACADA Journal 36(1): 30-42.

18. Habley, W (2004) The status of academic advising: findings from the ACT sixth annual survey. National Academic Advising Association Monograph Series Number 10. Manhattan Kansas.

19. Amin Y Noaman, Fekry Fouad Ahmed (2015) A New Framework for E Academic Advising, International Conference on Communication, Management and Information Technology, Procedia Computer Science. ScienceDirect 65(2015): 358-367. 

(C) This work is licensed under Creative DOI: 10.19080/ASM.2019.02.555591
Your next submission with Juniper Publishers will reach you the below assets

- Quality Editorial service

- Swift Peer Review

- Reprints availability

- E-prints Service

- Manuscript Podcast for convenient understanding

- Global attainment for your research

- Manuscript accessibility in different formats

( Pdf, E-pub, Full Text, Audio)

- Unceasing customer service

Track the below URL for one-step submission https://juniperpublishers.com/online-submission.php 